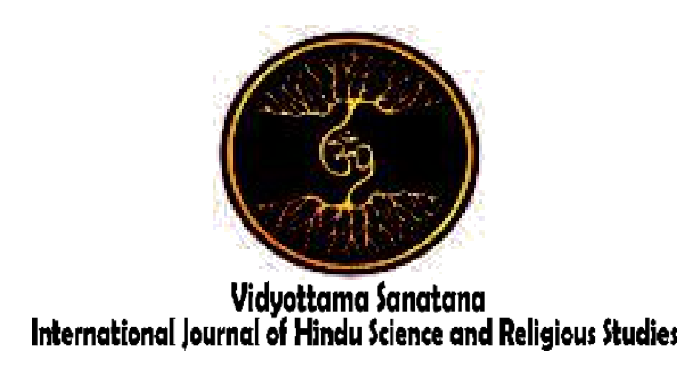

Vol. 3 No. 2 October 2019

\title{
SPIRITUAL MENTAL DEVELOPMENT THROUGH HINDU EDUCATION FOR HIV AIDS
}

\author{
By: \\ Inay Bhagwandas \\ Institute of Community Empowerment, Kolaka, India \\ E-mail : i_bhagwandas@gmail.om
}

Received: June 11, 2019

Accepted: August 22, 2019

Published: October 31, 2019

\begin{abstract}
Mental guidance refers to the formation of a complete personality with strong faith and physical strength. If a person's mental state does not get attention it will bring negative impacts. The fragility of one's mental endurance can be overcome by increasing the spiritual deepening of religion. In connection with this optimization of Hindu religious education is very influential in the development of mental and spiritual, especially among people with HIV AIDS. People with HIV AIDS must understand and implement religious teachings so as to avoid negative actions and harm themselves and others. Research on the mental and spiritual development of people with HIV AIDS through the Hindu religious education approach is important to be carried out, in addition to having never been investigated, it can also provide an illustration of tackling the spread of HIV AIDS and increasing the spirit of life for sufferers.
\end{abstract}

Keywords: Spiritual Mental, Hindu Religious Education, People with HIV AIDS

\section{INTRODUCTION}

Hinduism is one of the oldest religions of the world with no known beginning, no human founder. It predates recorded history. Hindus believe that there is one creator, all life is sacred, and therefore non-violence or Ahimsa is the highest Dharma of a Hindu. Belief in reincarnation gives continuity of life from one birth to the other until the soul is realized and reaches Nirvana. Ayurveda, an ancient Indian medical practice, is commonly used to treat patients. Other alternative medicines such as homeopathic treatments, message therapy are also commonly used for preventive as well as curative practices. Hindus in India tend to be 
more ritualistic than in the Western world.Treatment of Hindus has to be culturally sensitive and include Hindu beliefs and practices. Clinicians have to be aware that patients are rarely self-referred and the role of the family is crucial. Clinicians should distinguish between healthy and unhealthy religiosity based on how it interferes with adaptation to life situations (Juthani, 2001).

The existence of tourism with the majority of people upholding and carrying out religious teachings, apparently faced a severe challenge in reducing the spread of HIV AIDS which is dominated through the use of syringes (drugs) and free sex. The statement is in accordance with the opinion of the Titib. (1996: 2) that the problem of drug abuse and transmission of the HIV AIDS virus is not merely a health problem in a biological or physical sense, but is due to the weakening of the element of self-control, especially those concerning sexual behavior as objects of mere sense gratification. Social and cultural responsibility to become a healthy and prosperous generation plays a very important role in self-control efforts to prevent drug abuse and contract the HIV AIDS virus.

Humans living in the world must have strong faith so that they do not fall into unwanted things let alone suffer from HIV AIDS. Self-control is a reflection of sraddha (faith) in religious life that is related to oneself with fellow human beings, both in the family, community, nation and state even in international relations between nations. Self-control comes from sraddha which is the essence of the teachings of Hinduism as a belief in life and experience for a controlled life, very useful for realizing prosperity, harmony and happiness in life. Someone who has a strong faith and is able to control himself, will survive in this world and the hereafter. For this reason religion should truly be the basis and grip of everyone.

Hindu religious education originating in the vedas, revelations or the words of God Almighty is full of self-control teachings. The doctrine of self-control is part of the teachings of ethics, namely the doctrine of good and right behavior and avoiding bad and wrong deeds. This ethical teaching is a manifestation of the teachings of the faith which in Hinduism is known as Panca Sradha. If Hindus have sraddha or faith that is solid, certainly able to control themselves not to do something that is contrary to religious teachings, including in the relationship of fulfilling sexual drives that deviate or do it before marriage. One line definitions do not do justice to complex cultural concepts. There are many references in Indian philosophical texts as to what constitutes as an ideal person. Most often, quoted text is from Srimad Bhagavad Gita describing the balanced person as one who has a controlled mind, emotions and senses (Behere, Das, Yadav, \& Behere, 2013).

Hindu religious education becomes important to be promoted in the mental and spiritual development for people with HIV AIDS. Although on the other hand there are also opinions that state religious groups, still distant from the problem of HIV AIDS. Not only that, religionists also helped foster misconceptions about HIV and are considered curse or dirty disease. In addition, the perception of HIV transmission is only due to acts that violate religion, such as sexual behavior outside of marriage and changing partners. Whereas in society for example, HIV AIDS is transmitted to children who have never committed acts according to religion including that $\sin$. According to Hidayat (2006: 19) religion should be a tool to help other marginalized groups such as the poor, laborers, victims of violence, and so on. These glasses should be used as an effective tool to advocate for people with HIV and AIDS.

HIV is transmitted through a number of ways, including through unsafe sex, sharing needles and syringes, through mothers to their babies during pregnancy, childbirth, and breastfeeding and through blood transfusion. Until now there was no HIV transmission through other causes. HIV is not transmitted simply because of social activities. for example living in a house, 
eating together, kissing on the cheek, shaking hands, or even one cup of coffee together. Especially just because of a place of worship together. The contributor also must go through several conditions, namely one is HIV positive, there is a medium of transmission (blood, water semen, vaginal fluids), and there is an "entrance". as long as the conditions are not met there will be no transmission.

By means of transmission and the conditions stated above, most HIV and AIDS occur among injecting drug users with needles, those who change unprotected sexual partners either orally, vaginal or anal, and from mothers to children. Seeing the background of those at high risk of contracting it, religious groups tend to refer to them as "sinners".

The reality is that, HIV and AIDS is increasingly spreading. no longer only in groups known to be at high risk. In Singaraja, for example, HIV has begun to spread to children. Children who are mostly still toddlers are infected from the mother. The mother contracted from her father who had sexually changed partners without a condom. From this angle, religion should be able to defend people with HIV AIDS. involved in prevention efforts through prevention, care and assistance with PLHA. Religion is not only in the sacred, sacred, without touching the reality that continues to be blamed (Sutrisno: 2006: 8).

In connection with the above, Hindu religious education is very influential in the development of mental and spiritual development and increase understanding of the values of religious teachings. To explore, live and practice religious teachings, the role of parents, religious teachers and religious leaders is needed by providing direction, guidance so that people with HIV AIDS can live a normal life in society.

\section{METHOD}

The research method used is a qualitative method, where data collection techniques use observation, interviews, and literature study. Viewed from the source of the data collected, it is divided into two, namely primary data, meaning that the data obtained comes from the first source or directly obtained from the field. Primary data in this study are information obtained through informants regarding HIV AIDS prevention, and secondary data that is data obtained from second sources such as books, magazines, newspapers and relevant internet sources.

The method used in analyzing data is a qualitative descriptive method which is interpreted as a problem-solving procedure that is investigated by describing or describing the current state of the subject and object of research based on facts that seem as they are.

\section{RESULT AND DISCUSSION}

Coaching is basically an educational effort both formal and non-formal which is carried out consciously, planned, directed, organized, and responsible in introducing, growing, guiding, and developing a personality base that is balanced with talents, tendencies / desires and abilities as provisions for then on their own initiative to improve and develop themselves, each other and their environment towards the achievement of dignity, quality, and optimal human abilities and independent individuals.

The rapid development of science and technology (Science and Technology), also has a very big influence on the development of the world of education. Renewal in all fields continues to occur almost in all fields continues to occur almost in all aspects, in line with the development of new paradigms in the life of society, nation and state, so it also demands innovation in the field of Hindu religious education.

The world of education in Indonesia has experienced many changes, so the consequences have also caused many changes in terms of the formation of student behavior. In order to respond to the phenomena occurring in this era, educational experts are racing to develop education in all branches of science. At the same time, various crises in the social life of Indonesian 
people have emerged, such as economic crises, social crises, and often referred to as dimensional crises, which require changes in the value of life in the field of education, both family education, school education and non-formal education.

The essence of Hindu religious education must be able to build students into human beings who understand, appreciate and be able to reflect the knowledge they have in their way of thinking, speech and daily actions in the smallest or primary environment, a place to explore knowledge , as well as in a wider environment that is the community in which the child interacts.

Hindu subjects are religious subjects whose instructors focus on the formation of mental attitudes and good ethical values. The basic education curriculum (2004) emphasizes the nature of Hindu religious education which is expected to be achieved are:

1. Students have the knowledge and beliefs of Hinduism and are able to implement the concept of Hinduism in daily life that is reflected in the attitude of Iqwa Ida Sang Hyang Widhi or a god who is almighty, respectful mutual respect and affection for fellow human beings.

2. Forming a whole, moral and wise human being, that is, a person who can live the nature of this life (full of challenges and suffering), also forms a human who knows the cause of suffering and people who believe that however much the form of suffering will be eliminated, because it has been known a way that can free humanity from that suffering.

3. By living and practicing the teachings of Hinduism, it is hoped that students can increase their diverse awareness, through Hindu religious education it can also be instilled in the awareness of the community, nation and state. Hinduism, so that through understanding Hindu religious education the true human students will become moral.
4. Prevention is to ward off negative things from the environment or foreign culture that can endanger students and hinder the development of students towards Indonesia as a whole.

5. Adjustment, that is adjusting to the physical environment as well as the physical and social environment in accordance with religious teachings.

6. Sources of value, which provides guidelines for achieving happiness in the world and in the hereafter born and bhatin.

The elementary school Hindu religious education curriculum (1999) emphasizes that the nature of Hindu religious education in primary schools is:

1. Students have the knowledge and beliefs of Hinduism and are able to implement the concepts of Hinduism in daily life that are reflected in the attitude of piety to God Almighty, mutual respect and compassion towards fellow human beings.

2. Forming a whole, moral and wise human being that can live the nature of life (which is full of challenges and suffering), also forming a human who knows the cause of suffering and people who believe that however any form of suffering can be eliminated, because it is not known a way that can free people from suffering.

3. By living and practicing Hinduism teachings, students are expected to be able to increase their diverse awareness, in social life, as a nation and state. Hindu religious education is a guide to mental attitude and personality both in personal life and in relations with the community, nation and country, and the natural surroundings (Elementary Hindu Religious Education curriculum 1999).

The opinion above is also supported by the opinion generated based on the Unity of Interpretation of Aspects of Hinduism (1986: 24) states that the nature of Hindu religious 
education in schools is as follows (1) forming a pancasialis and astiti devoted people, (2) forming morals and ethics and spiritual of students in accordance with the teachings of Hinduism.

To overcome the obstacles in conducting mental and spiritual guidance of HIV AIDS sufferers, it is necessary to have efforts in overcoming the problems that occur to achieve the goals to be achieved, so that people with HIV become human beings who have noble personality and act in accordance with the teachings of Hinduism.

As an HIV/AIDS diagnosis carries with it unique stigma and prejudice, general measures of spirituality, while useful to compare across disease populations, do not tap into the unique experiences of people with HIV/AIDS with regards to potential changes in their religiousness and spirituality. As a result, we proposed in this study: (1) to describe the changes in religiousness and spirituality in people with HIV/AIDS that they perceive to be attributable to their HIV/AIDS diagnosis; and, as such perceived changes are likely to vary within the HIV/AIDS population by sociodemographic characteristics, (2) to determine if these perceived changes differ by sex and race. We hypothesized that the majority of participants would perceive themselves to have experienced changes in their religiousness and/or spirituality since being diagnosed with HIV/AIDS, and that changes would differ by race and sex. Specifically, we speculated that women and African Americans would report more religiousness and spirituality since their HIV/AIDS diagnosis and greater belief that their religious/spiritual beliefs had lengthened their life than men and Caucasians, respectively Chandra, Satyanarayana, Satishchandra, Satish, \& Kumar, 2009).

The efforts made in fostering the mental and spiritual sufferers of HIV AIDS in the community are as follows:
1. Increasing the role of parents in fostering the spiritual and mental health of people with HIV AIDS.

The role of parents is very big influence in fostering the mental and spiritual sufferers of HIV AIDS. Where support from parents will provide encouragement for people with HIV in living their lives. and the role of parents who have been shown to PLHAs is to visit their children who have HIV AIDS in this community once a week. Besides the role of parents, especially those who are Hindu, every time there is a full moon, tilem, kajeng kliwon and other Hindu religious ceremonies will surely give their children ceremonial equipment (incense, flowers, canang, tirta) to carry out prayers in the holy place.

People with HIV AIDS cannot be denied that they are still discriminated against by the community or no longer accepted by parents or families even though parents who must encourage their children who have HIV AIDS. Although they cannot cure their children from HIV AIDS, parents should provide spiritual support, for example educating their children about religious teachings. Even though they have HIV AIDS, PLHAs also need religious teachings not to do anything that can harm themselves.

Parents of people with HIV who have children, can not do much to cure their children who have HIV AIDS, because until now there is no drug that can cure the disease. Only with spiritual support can parents do their children. So they can get closer to God Almighty.

2. Increase the role of religious leaders in fostering mental and spiritual sufferers with HIV AIDS

In providing mental and spiritual guidance through Hindu religious education the role of Hindu religious leaders is needed, because the task of Hindu religious leaders is to provide counseling to Hindus both parents and adolescents. With the aim of providing direction and guidance so that Hindus 
become mentally human beings in accordance with the ideology and will have a firm belief and diligently carry out religious teachings. The role of Hindu religious leaders in giving spiritual relief to people with HIV AIDS is indeed very necessary, it is intended that people with HIV AIDS do not always feel guilty because they have the disease. In addition, the role of religious leaders is very important for people with HIV AIDS so that people can better understand the teachings of religion and of course also how to implement it in everyday life. Results indicated that religious coping was a salient construct for Hindus and related to better mental health. Empirical data revealed specific forms of religious coping that are characteristic of Hindu theology (Tarakeshwar, Pargament, \& Mahoney, 2003).

Mental spiritual development is carried out by Hindu religious leaders by conveying religious messages through the methods of aji santi and karma santi which aim to improve Sraddha and Bhakti as religious people. The method of santi aji is to convey knowledge about religion such as: Dharma Discourse and Yoga.

1. Dharma Discourse is a method of illuminating Hinduism which is presented at every opportunity before PLHAs relating to religious activities. The goal to be achieved is to increase knowledge, appreciation, practice in the spiritual community and the devotion to the religion, society, nation and state. The material presented at every opportunity, basically covers aspects of Hindu religious teachings that are associated with life. In its delivery, it can be used with language that is easily understood, internalized and impregnated by people with HIV, so that the desired goal will be achieved.

2. Dharma Gita is a religious song. Traditionally it has been implemented throughout Indonesia. Dharma Gita as a medium to convey and deepen religious beliefs that hold its role is very effective. It also aims to preserve and preserve traditional cultural heritage which is enshrined to the majesty of religion. Besides that, through dharma gita it is hoped that it will also be able to provide a sense of purity, respect and specificity in the implementation of religious activities.

3. Yoga is a form of self-control, yoga is important given to people with HIV to form a mindset that is based on religious teachings, so as to be able to divert the attention of PLHAs to do positive things and distance themselves from negative things.

After the three things related to Hindu religious education were given to people with HIV, people with HIV were very enthusiastic to follow it. Dharma discourse, which is given every three months by community leaders, has never been absent, attended by Hindu PLHAs who are non-Hindu and PLHAs who are nonHindus are also very enthusiastic to listen to Dharma Discourse given by informants.

Because of their weak immune system, people with HIV AIDS (PLHAs) are very vulnerable to various diseases. This is because, HIV attacks a person's immune system. As a result, people with HIV also have a lower resistance to disease than normal people or people who do not live with HIV AIDS. The immune system of people with HIV decreases due to white blood cells or known as CD4 cells continue to be undermined by HIV.

People with HIV AIDS have to do exercise to increase energy, fight fatigue and depression. Exercise can also improve the health of the immune system. Because a lot of positive benefits derived from the 
sport for people with HIV. People with HIV AIDS really need exercise so that the immune system remains strong. And in Hinduism there is yoga that can be done by people with HIV AIDS in addition to being able to move the body so that the immune system remains strong yoga is also useful to calm the mind, especially for people with HIV AIDS, yoga is very necessary to form a good body and soul.

The benefits that have been obtained by people with HIV while participating in yoga programs are improving sleep patterns and increasing appetite, helping to hold and decrease CD4 cell counts, and the benefits that PLHAs receive during yoga can reduce stress. Exercise cannot control HIV, but helps people with HIV feel healthier in fighting the various effects of HIV and the side effects of drugs used by people with HIV.

3. Increase the role of the community in fostering the mental and spiritual sufferers of HIV AIDS.

There are still many people who intentionally or unintentionally discriminate against people with HIV and AIDS is evidence that advocacy and information about HIV transmission to the community is not optimal. Regarding the role of the community in fostering the mental and spiritual sufferers of HIV AIDS during one month of counseling conducted to the community there is a positive impact that has been shown by the community to people with HIV, one of which is the acceptance of people living with HIV in activities carried out in the community, including in ceremonies conducted at temples can already the receipt of HIV AIDS sufferers to foster and discriminate against people with HIV gradually begins to be overcome besides that at this time the community has formed KDPA which is an organization of village cadres who care about HIV AIDS. Indeed there are still people who discriminate against people with HIV AIDS, this happens because I still forbid understanding in the community about how HIV AIDS is transmitted and prevented. The community should carry out HIV AIDS like ordinary people and do not discriminate against people with HIV AIDS. The main objective is to make the problem of sexually transmitted infections (STIs), including HIV and AIDS, a part of the problems of villagers. But the other goal is to erase the stigma that the HIV AIDS problem is only a group of sinners as well as the myth that villagers will not be touched by this problem. Because, facts show, villagers are also vulnerable to being affected by HIV and AIDS. During this time the view in the community said that people who live in cities only have HIV AIDS even though people in the village can also have HIV AIDS by the role of religious education is needed by the community so that they can avoid negative things Because there are still people who see people with HIV as people who deserve illness due to their actions in the past. Therefore not all friends in their daily lives can help people with HIV. People with HIV AIDS need friends who are committed, understand each other and accept (in positive terms, of course).

This is where the importance of organizations, whether in groups, groups, forums or whatever they are called, in which there are people who have a common goal of assisting people with HIV AIDS to be people who do not easily give up, surrender, let alone become people who are weak due to HIV disease AIDS.

The alienation that has existed between the mental health professions and religion for most of the 20th century is ending. The influence of the naturalistic, antireligious assumptions that once gripped the field have weakened, and there is now a more spiritually open zeitgeist or "spirit of the times." During the 1990s, many articles on religious and spiritual issues in mental health and psychotherapy were published in mainstream journals. Numerous 
presentations on these topics were also given at conventions of mental health organizations (Richards, \& Bergin, 2000).

Apart from this the community also formed a peer support group. Peer groups are a place for mutual support, hope and strength for people living with HIV and AIDS. This group is very helpful for PLHAs with their health problems. In this group usually people with HIV and AIDS feel comfortable and have the support of fellow group members. With the presence of peer support groups, the life burden of people with HIV AIDS becomes lighter. Because, in this group all members gain knowledge in order to be able to empower themselves and their fellow members.

\section{CONCLUSIONS}

Based on what has been described in previous chapters, a conclusion can be drawn as follows:

1. Hindu religious education has an important role in fostering the mental and spiritual sufferers of HIV AIDS, to increase the sense of devotion to God. Besides Hindu education also plays a role in increasing understanding of the values of religious teachings in which teach advice, norms of decency and ethics that need to be implemented, so that PLHAs have strong sradha and devotion.

2. Efforts made in fostering mental and spiritual sufferers with HIV AIDS are increasing the role of parents, where parents are the closest people to people with HIV, increasing the role of religious leaders, so that people with HIV understand the teachings of Religion more, increasing the role of the community, so that it does not happen again Discrimination against people with HIV.

3. Barriers to the mental and spiritual development of people with HIV / AIDS are stigma and discrimination against people living with HIV, there is still difficulty in obtaining funding for activities carried out, religious leaders have not been maximized in instilling religious values in PLHAs, and there is still a lack of information true in the community and people with HIV about what is meant by HIV AIDS, transmission and prevention.

\section{REFERENCES}

Behere, P. B., Das, A., Yadav, R., \& Behere, A. P. (2013). Religion and mental health. Indian journal of psychiatry, 55(Suppl 2), S187.

Chandra, P. S., Satyanarayana, V. A., Satishchandra, P., Satish, K. S., \& Kumar, M. (2009). Do men and women with HIV differ in their quality of life? A study from South India. AIDS and Behavior, 13(1), 110-117.

Juthani, N. V. (2001). Psychiatric treatment of Hindus. International Review of Psychiatry, 13(2), 125-130.

Richards, P. S., \& Bergin, A. E. (2000). Toward religious and spiritual competency for mental health professionals.

Tarakeshwar, N., Pargament, K. I., \& Mahoney, A. (2003). Initial development of a measure of religious coping among Hindus. Journal of Community Psychology, 31(6), 607628. 